\title{
In vitro transcription of the Drosophila engrailed gene
}

\author{
Walter C. Soeller, Stephen J. Poole, and Thomas Kornberg \\ Department of Biochemistry, University of California, San Francisco, California 94143 USA
}

An enzyme system that accurately initiates transcription of the engrailed gene has been prepared from Drosophila embryos. The system has been separated chromatographically into two fractions, both of which are required for specific engrailed transcription. DNase footprint and competition analysis detected at least two sequence-specific DNA-binding proteins in one of these two fractions. Together, these proteins bind to eight regions within $400 \mathrm{bp}$ of the transcription initiation sites. Most of the regions containing these binding sites are required for manimal engrailed transcription in vitro. In addition, a region downstream from the initiation sites and within the first 40 residues of the transcription unit is essential for transcription. Transient in vivo expression assays indicated that these same upstream and downstream sequences are required for transcription in Drosophila tissue culture cells.

[Key Words: Drosophila; engrailed; transcription]

Received August 17, 1987; revised version accepted November 23, 1987.

The structure of the Drosophila engrailed gene is highly unusual. Mutations in the gene are spread over a $70 \mathrm{~kb}$ region of the genome, yet its single transcription unit is less than $4 \mathrm{~kb}$ in length (Drees et al. 1987). Flanking its transcription unit are transcriptionally silent regions that extend for $20 \mathrm{~kb}$ downstream and $45 \mathrm{~kb}$ upstream, suggesting complex and perhaps novel regulatory mechanisms. To understand the role of these flanking regions, and learn how expression of the engrailed gene is regulated, we have developed a system that faithfully initiates engrailed transcripts in vitro.

The central importance of transcriptional regulation in generating the temporal and spatial patterns of engrailed gene expression has been suggested by several observations. Mutations that alter the structure of the gene's untranscribed flanking regions affect both the quantity and disposition of engrailed transcripts (Weir and Kornberg 1985; and unpubl.). Also, the distinctive expression in the early embryo, in which single-cellwide stripes of cells express the engrailed gene in each of the segmental primordia, is the result of an extremely rapid stepwise progression in a temporal pathway (Weir and Kornberg 1985). This progression initiates with 3 broad stripes, proceeds to a pattern with multiple stripes that alternate in intensity, and eventually results in 14 equally spaced zebra-like bands in blastoderm stage embryos (T. Karr, M. Weir, and T. Kornberg, in prep.). At this developmental stage, engrailed RNA has a half-life of approximately $15 \mathrm{~min}(\mathrm{M}$. Weir and $\mathrm{T}$. Kornberg, unpubl.), and the progression of patterns is completed within $90 \mathrm{~min}$. Such rapid and dramatic changes are likely to be under transcriptional control.
Regulation of engrailed gene expression has been investigated genetically. The engrailed gene is not expressed in even-skipped mutant embryos (Harding et al. 1986), and engrailed gene expression is also affected in hairy and fushi tarazu mutant embryos (Howard and Ingham 1986). Thus, the even-skipped, hairy, and fushi tarazu genes are required for the normal expression patterns of the engrailed gene. Although these studies do not indicate how this requirement is manifested at a molecular level, it is possible that the protein products of these genes directly regulate engrailed gene transcription.

An alternate approach to probing the mechanisms that control expression of the engrailed gene is to reconstruct the transcriptional regulation in vitro. In vitro systems from many cell and animal sources have been described that accurately reconstruct RNA polymerase II initiation (Dignam et al. 1983; Manley 1983). Several systems derived from mammalian sources have been shown to exhibit regulation in response to tissue-specific factors (Mizushima-Sugano and Roeder 1986; Gorski et al. 1986). In Drosophila systems, extracts of Drosophila tissue culture cell nuclei have been shown to initiate accurately from the promoters of Drosophila heat shock, alcohol dehydrogenase, actin, and histone genes (Parker and Topol 1984a,b; Heberlein et al. 1985). Such tissueculture-derived systems unfortunately yield only small amounts of enzymes for biochemical characterization, and they cannot take advantage of either the rich genetic heritage of Drosophila or of its readily accessible developmentally staged populations. In this study, we have developed a method to prepare extracts from Drosophila 
embryos, and have shown that these extracts can accurately initiate transcription of several Drosophila genes. We use this system to investigate transcription of the engrailed gene with the aim of elucidating the complex mechanisms that regulate this transcription.

\section{Results}

\section{In vitro transcription in Drosophila embryo extracts}

A cell-free extract of Drosophila embryos was prepared and assayed for its ability to transcribe a number of templates containing cloned Drosophila promoters. These templates were cleaved at sites downstream from the in vivo initiation sites and were used in run-off assays (Fig. $1 \mathrm{~A})$. The major run-off RNA product, $1.1 \mathrm{~kb}, 1.2 \mathrm{~kb}$, and $1.4 \mathrm{~kb}$ in length for the fushi tarazu, alcohol dehydrogenase (Adh), and actin $5 \mathrm{C}$ genes, respectively, in each case corresponds to a transcript initiating at the in vivo start sites (Fyrberg et al. 1980, Benyajati et al. 1983; Laughon and Scott 1984). The size of the run-off transcript from an engrailed template $(1.3 \mathrm{~kb})$ was also consistent with the in vivo initiation sites (Drees et al. 1987). Under these conditions of template and extract concentrations, the relative efficiencies of the fushi tarazu, Adh, actin 5C, and engrailed templates were approximately $10: 5: 4: 1$, respectively. For the engrailed template, the rate of product accumulation was constant for a 30 - min incubation (data not shown), and the amount of RNA synthesized was proportional to the template concentration. Maximal incorporation was at $40 \mu \mathrm{g} / \mathrm{ml}$ DNA in the presence of $125 \mu \mathrm{g}$ crude extract (Fig. 1B).

A primer extension assay was used to compare the in vitro initiation sites with the sites utilized in vivo. A 5 '-end-labeled oligonucleotide was hybridized to RNA that had been synthesized in vitro or isolated from Drosophila embryos, these were elongated with reverse transcriptase, and the products were fractionated by electrophoresis (Fig. 2A). Transcription initiates in vitro at a cluster of closely spaced sites identical to those used in vivo. These are designated by their nucleotide spacing in the direction of transcription, with the major sites of initiation at residues $+1,+2,+5$, and +6 . The Drosophila embryo extracts therefore accurately initiate transcription from the engrailed promoter.

\section{Fractionation of the embryo extract}

The embryo extract was fractionated by a procedure that has been used previously to identify transcription components of HeLa cells (Dynan and Tiian 1983) and Drosophila tissue culture $\mathrm{K}_{\mathrm{c}}$ cells (Heberlein et al. 1985). After dialysis, the crude extract was applied to a heparin-Sepharose column and eluted with $0.4 \mathrm{M} \mathrm{KCl}$ (fraction H.4; nomenclature of Heberlein et al. 1985). The H.4 fraction was applied to a DEAE-Sepharose column from which a break-through fraction (D.1) and a
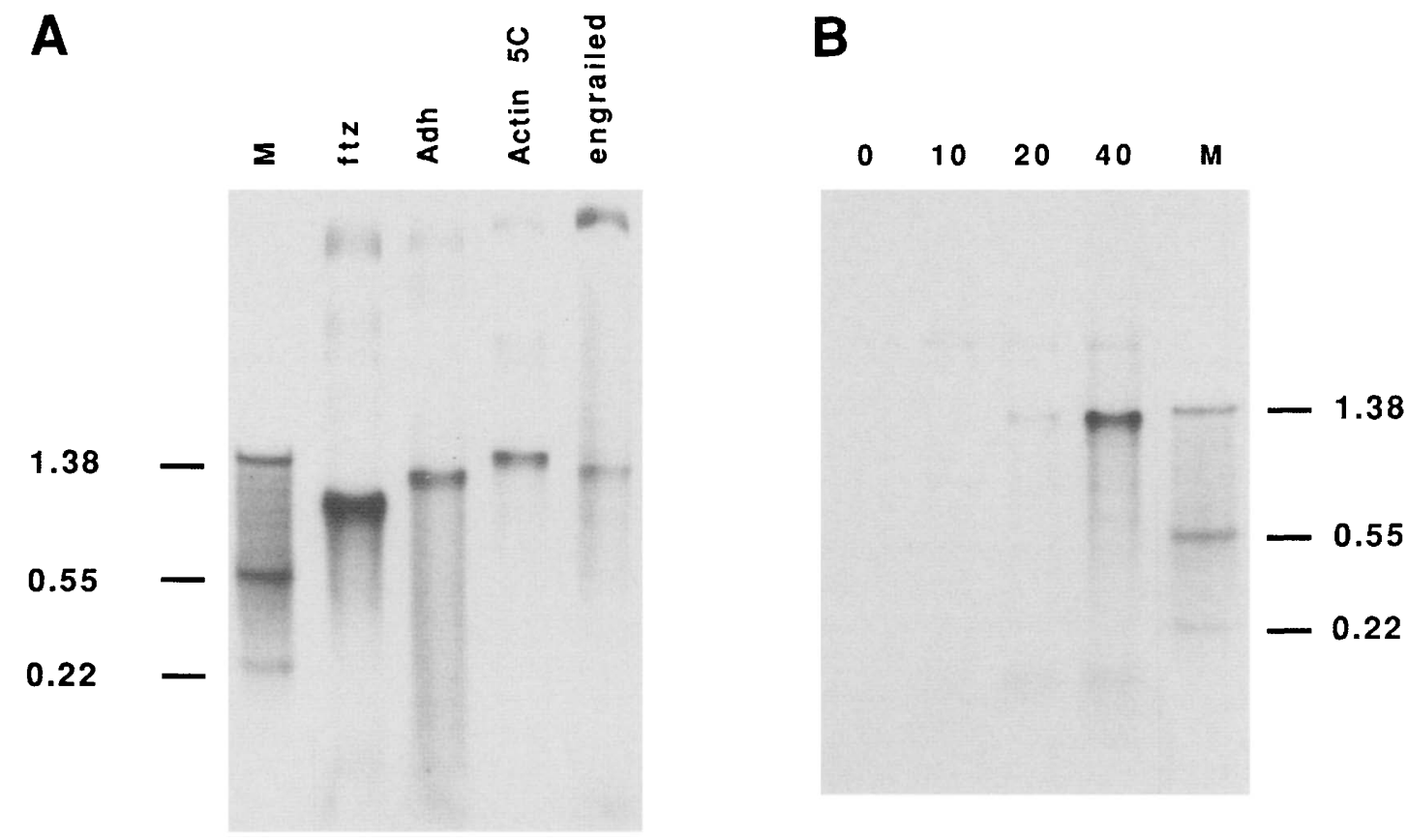

Figure 1. Run-off transcripts synthesized by embryo extracts. (A) Assay of various templates bearing Drosophila promoters. The indicated template DNAs $(20 \mu \mathrm{g} / \mathrm{ml})$ were each incubated with extract from embryos $(5 \mathrm{mg} / \mathrm{ml}$ final protein concentration $)$ as described in Experimental procedures. (Lane M) Marker RNAs generated by T7 RNA polymerase whose lengths are indicated in kilobases (kb). Template DNAs were digested as follows: (lane ftz) AvaI; [lane Adh (pl3E-3)] BamHl; [lane Actin 5C (pDmA $)$ HindIII; [lane engrailed plasmid (p6:4.7)] XhoI. The expected run-off transcripts are 1.1, 1.2, 1.4, and $1.3 \mathrm{~kb}$, respectively. $(B)$ Titration of engrailed DNA template. Increasing concentrations of plasmid p6:4.7 digested with XhoI were incubated with $125 \mu \mathrm{g}$ crude nuclear extract from embryos. (Lane M) Markers as in $A$. 


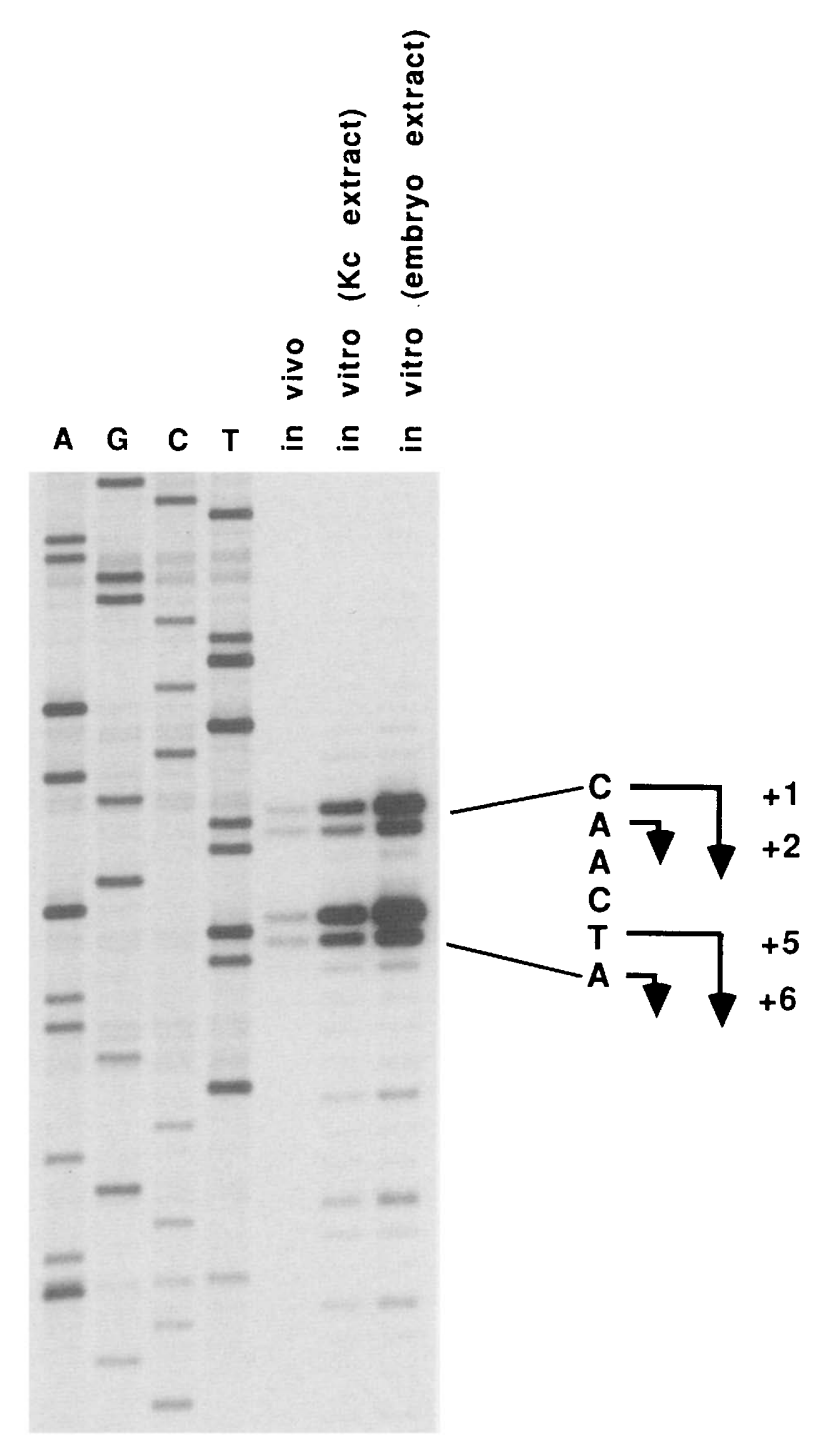

Figure 2. Identification of in vivo and in vitro initiation sites. A primer extension assay with primer 1 (which hybridizes to the coding strand from nucleotide positions +58 to +39 , inclusive/ was utilized to map the exact sites of initiation as described in Experimental procedures. Sequencing reactions were by the dideoxynucleotide termination method and used the coding strand as template. The sequence printed next to the primer extension products is that of the coding strand. The position to which the longest primer extension product maps is defined as +1 ; the adjacent upstream position is defined as -1 . The complete sequence of this region is in Fig. 5C.

fraction that contained proteins that eluted with $0.25 \mathrm{M}$ $\mathrm{KCl}$ (D.25 fraction) were collected.

Each of these protein fractions was tested for transcriptional activity on an engrailed template using a primer extension assay (Fig. 3). The crude extract and H.4 fractions alone were active, whereas the D.1 and D.25 fractions were not. However, transcription activity was restored when the D.1 and D.25 fractions were combined. Transcription activity was sensitive to 0.5 $\mu \mathrm{g} / \mathrm{ml} \alpha$-amanitin, indicating that RNA polymerase II is an essential component. Although the identities of the other components of these DEAE fractions have yet to be established, RNA polymerase II activity was unevenly distributed between them. On a template of single-stranded calf thymus DNA, $90 \%$ of the RNA polymerase II activity was present in the D. 25 fraction. These results suggest that both DEAE fractions contain essential components: the D.25 has RNA polymerase II activity and the D.1 has some component(s) that enhance(s) specific transcriptional initiation from the engrailed promoter. Since the D. 25 fraction could not be replaced in the reaction by a preparation of RNA polymerase II purified from Drosophila embryos (Coulter and Greenleaf 1982), either a distinct RNA polymerase II subspecies in the D. 25 fraction is involved, or the RNA polymerase purified by an assay using a nonselective calf thymus DNA template is inactive in this initiation reaction (Kim and Dahmus 1986), or the required D. 25 component(s) include additional activities.

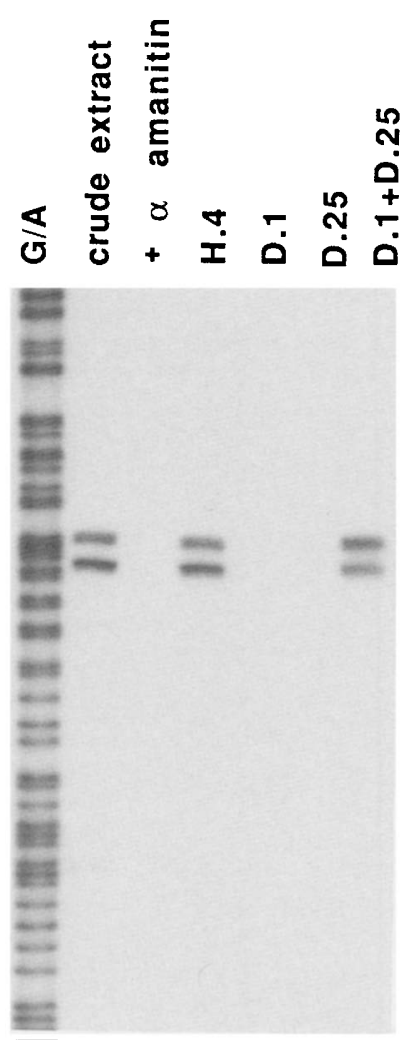

Figure 3. Reconstruction of engrailed transcription with partially purified protein fractions. The engrailed template $10.5 \mu \mathrm{g}$ of p6:4.7) was incubated with various protein fractions (crude extract and H.4, $80 \mu$ g protein; D. 1 alone, $30 \mu \mathrm{g}$; D. 25 alone, 24 $\mu \mathrm{g}$; D. 1 and D.25, 15 and $12 \mu \mathrm{g}$ protein, respectively) as described in the text. Primer 2 (which hybridizes to the coding strand from nucleotide position +167 to +148 , inclusive) was used to reverse transcribe the RNA products. A Maxam and Gilbert sequencing reaction (G/A) was electrophoresed in an adjacent lane for size reference. Because of the large size of the extension products, they are resolved as two bands, although further electrophoresis would resolve them as four bands (see Fig. 2). Where indicated, $\alpha$-amanitin was added to a final concentration of $0.5 \mu \mathrm{g} / \mathrm{ml}$. 
+231 TO -305 ENGRAILED PROMOTER FRAGMENT NONCODING STRAND

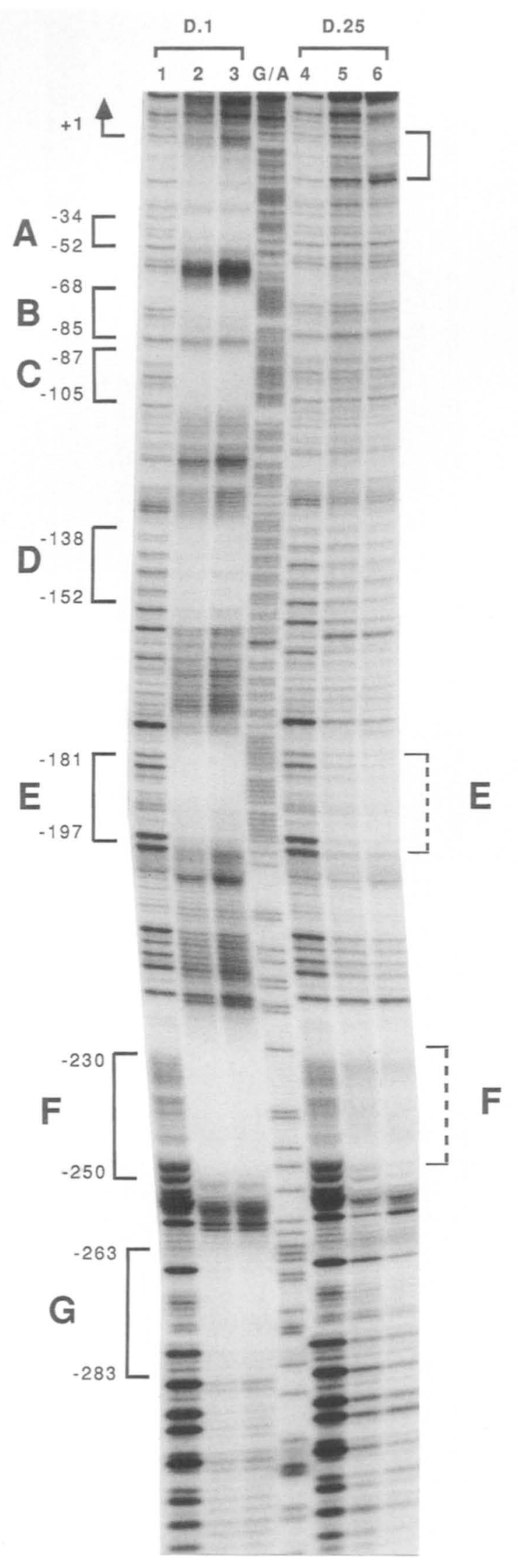

\section{DNase I footprint analysis of the engrailed promoter}

To analyze the activity conferring specificity on initiation of engrailed transcription, the capacity of the D.1 and D. 25 fractions to protect the promoter region from DNase I digestion was determined. Several probes were used. The first was designed to investigate the first several hundred nucleotides of sequence upstream of the start sites. It extended from position -305 to +231 and was labeled at position -305 . Increasing amounts of D.1 were incubated with this probe prior to partial degradation with DNase I (Fig. 4). Seven distinct regions of protection were detected (labeled A-G), the most proximal site (A) mapping to position -34 to -52 , and the most distal site (G) mapping between positions -263 and -283 . The lengths of the protected regions varied from 14 to 22 residues, and the distances between any two adjacent sites (other than $\mathrm{B}$ and $\mathrm{C}$ ) varied from 11 to 38 residues. The extent of cleavage in the region between sites A and B was strongly enhanced in the presence of some preparations of the D.1 (or H.4, not shown) protein fractions (Fig. 4) but not others (Fig. 5). The source of this variability is not known.

In contrast, D.25 retained little sequence-specific binding activity. With D.25, regions $\mathrm{E}$ and $\mathrm{F}$ were only partially protected, and no protection was observed for the other regions. This experiment did reveal the presence of a new binding activity whose target sequence $(-9$ to +10$)$ includes the initiation sites. This activity could represent a subspecies of RNA polymerase II, or it could be one of its accessory factors. Purified RNA polymerase II did not bind to this region in these footprint reactions (data not shown).

Using a DNA fragment that extended further upstream, from residues -38 to -419 , a protected sequence, called region $\mathrm{H}$, was found to extend from nucleotides -305 to -348 (Fig. 5A). The length of this region is more than twice that of any of the seven other binding sites, and it contains four copies of the pentamer sequence GAGAG (CTCTC). This sequence is also in the center of regions A, B, C, E, and F. Of the protected regions in which this sequence was not found, region $\mathrm{D}$ has repeats of the sequence GAGTG (or CACTC). Re-

Figure 4. Footprint analysis of the engrailed promoter upstream of its initiation sites. Reactions were carried out as described in Experimental procedures. The probe extended from position +231 to -305 and was labeled at the -305 position by a 3 '-end-filling reaction. Shown is the region from +20 to -300 . (Lanes 1 and 4) DNase I digests of the probe in the absence of any embryo protein fraction. (Lanes 2 and 3) Binding reactions and DNase digests in the presence of 30 and $60 \mu \mathrm{g}$ fraction D.1 protein, respectively. (Lanes 5 and 6 ) Reactions were carried out in the presence of 15 and $30 \mu \mathrm{g}$ fraction D. 25 protein. Regions of reduced or absent DNase cleavage sites are bracketed and labeled $A-G$. The upturned arrow marks the position of the first of the four initiation sites. Dashed brackets refer to regions of weak protection from DNase cleavage. The unlabeled bracket adjacent to lane 6 denotes the target sequence of a new binding activity present in the D.25 fraction and described in the text. 


\section{A}

-38 TO -419 ENGRAILED PROMOTER FRAGMENT NONCODING

CODING

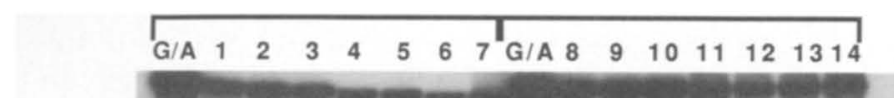

$\rrbracket_{-304}^{-350} \mathrm{H}$

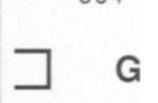

F

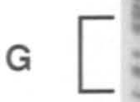<smiles>[CH]1CC[AlH]1</smiles>

ए 츤 $=-2$ $\leqslant$ 드르플 $\therefore=$ $\therefore=$

$-305$ $+2$

H 348 $=-$

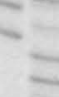
$-2=$

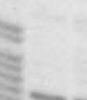

$-\infty$

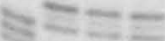

$x^{2}=-2=$

its

$+\infty-1$

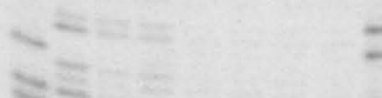

$\leqslant$

$5-\infty$

2

$\rightarrow-2-2=-$

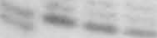

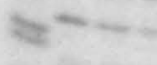

the

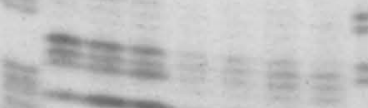

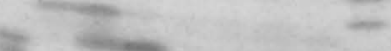

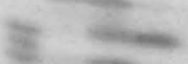

B $\quad-38$ TO -419 ENGRAILED PROMOTER FRAGMENT NONCODING STRAND

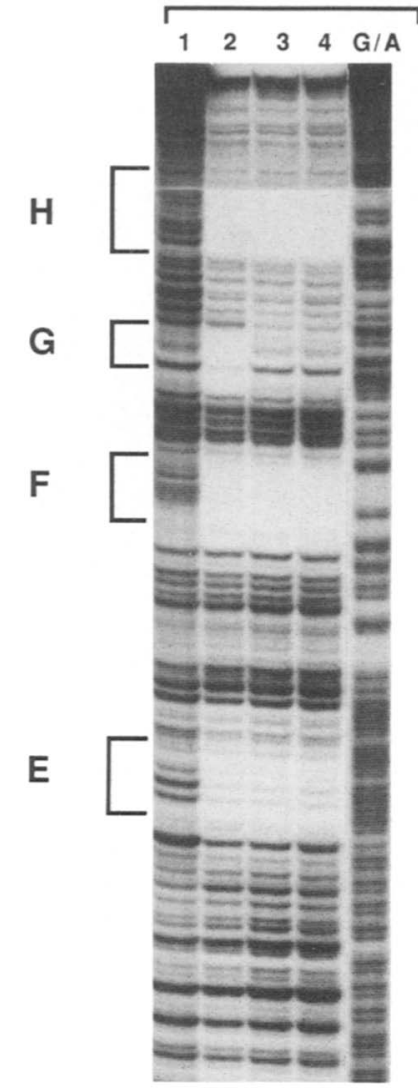

C

B

A

Figure 5. (See facing page for legend.) 
gion $G$, which has imperfect dyad symmetry, has no similar sequence. The nucleotide sequence from -422 to +216 and the footprinted regions are shown in Figure $5 \mathrm{C}$.

The number of distinct binding activities responsible for the eight protected regions was established by competition binding assays. A double-stranded oligonucleotide consisting of the 19 residues of region $\mathrm{C}$ was incubated in the presence of the $-38 /-419$ probe and fraction $\mathrm{H} .4$ (Fig. 5A). As the ratio of unlabeled competitor DNA to probe DNA was increased, protection at the six binding sites that contain the GAGAG pentamer disappeared. Region D contains the related pentanucleotide GAGTG, and its protection was consistently weak relative to the other regions, suggesting that its affinity for the binding protein is weak. The footprint of region $D$ was also competed by the region $\mathrm{C}$ oligonucleotide. Only region $G$ protection was unaffected in the presence of the region $C$ competitor. In contrast, when a 60-bp AvaI/DdeI DNA fragment containing region $\mathrm{G}$ was used as a competitor, it suppressed protection only at region $\mathrm{G}$ (Fig. 5B). Thus, there appear to be two distinct binding activities specific for the engrailed promoter: one binds to sites containing the pentanucleotide sequence GAGAG (or CTCTC); the other recognizes a single site, region $\mathrm{G}$, whose sequence contains dyad symmetry.
Upstream sequences are required for engrailed transcription

If the DNA-binding proteins that recognize sequences upstream of the engrailed initiation sites are involved in promoting transcription, then removing these upstream sequences should affect the fidelity or efficiency of RNA polymerase II initiation. To evaluate the role of these sequences, 18 templates were constructed that retained various lengths of engrailed DNA upstream of the initiation sites (Fig. 6A). These templates ranged from $\Delta-887$ (retaining $887 \mathrm{bp}$ upstream of the first initiation site and $231 \mathrm{bp}$ downstream) to $\Delta+15$ (retaining only engrailed DNA from the downstream positions +15 to +231 ). Relative transcription activities of these DNAs were determined. Each reaction mixture also contained a control template consisting of engrailed promoter DNA with a 15-bp insertion downstream from the initiation sites. Transcripts from this internal control template could be readily distinguished by their increased length, permitting a direct comparison of the template efficiencies of the different promoter deletions. Template efficiencies of 18 promoter fragments were compared qualitatively by inspection of autoradiograms after electrophoretic separation of their primer extension products. Quantitative comparisons were made from densitometric scans of the autoradiograms. Densito-

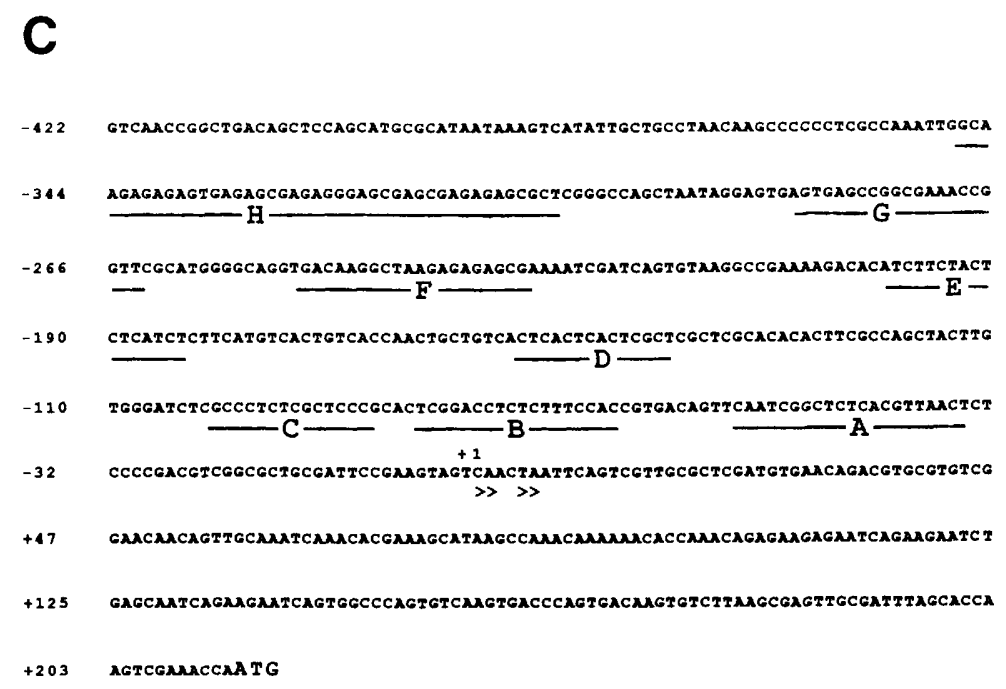

Figure 5. Footprint analysis of the engrailed promoter in the presence of competitor DNAs. (A) A probe extending from position -38 to -419 was labeled at either the downstream (coding) end or the downstream noncoding end by a 3 '-end-filling reaction. Size markers were from Maxam and Gilbert G/A sequencing reactions. DNase digestions were carried out as described in Experimental procedures with the following additions: (lanes 1 and 8) no added protein fraction; (lanes 2 and 9) $1.4 \mu \mathrm{g}$ fraction $\mathrm{H} .4$; (lanes 3 and 10) $14 \mu \mathrm{g}$ fraction H.4; (lanes 4 and 11) $14 \mu \mathrm{g}$ of $\mathrm{H} .4$ and $1.0 \mu \mathrm{g}$ poly(dI/dC) (as a nonspecific competitor); (lanes 5-7, 12-14) identical to lanes 4 and 11 except for increasing amounts of region $C$ oligonucleotide as competitor $(4-, 40-$, and 400 -fold molar excess of sites, respectively; see text). (B) Same fragment and procedure as in $A$ with only the noncoding strand labeled with polynucleotide kinase: (lane 1), no added extract protein; (lane 2) $14 \mu \mathrm{g}$ fraction $\mathrm{H} .4$ and $1.0 \mu \mathrm{g}$ poly/dI/dC); (lanes 3 and 4) same as lane 2 except that a $4-$ and 40-fold molar excess of a specific region G competitor (see text) was added, respectively. (C) The DNA sequence of the coding strand surrounding the engrailed initiation sites is shown and the location of the eight footprinted regions on the engrailed promoter are indicated. The four initiation sites are represented by $>$ and the first is labeled as +1 . The engrailed translational initation codon is presented in larger and bold type. 
A

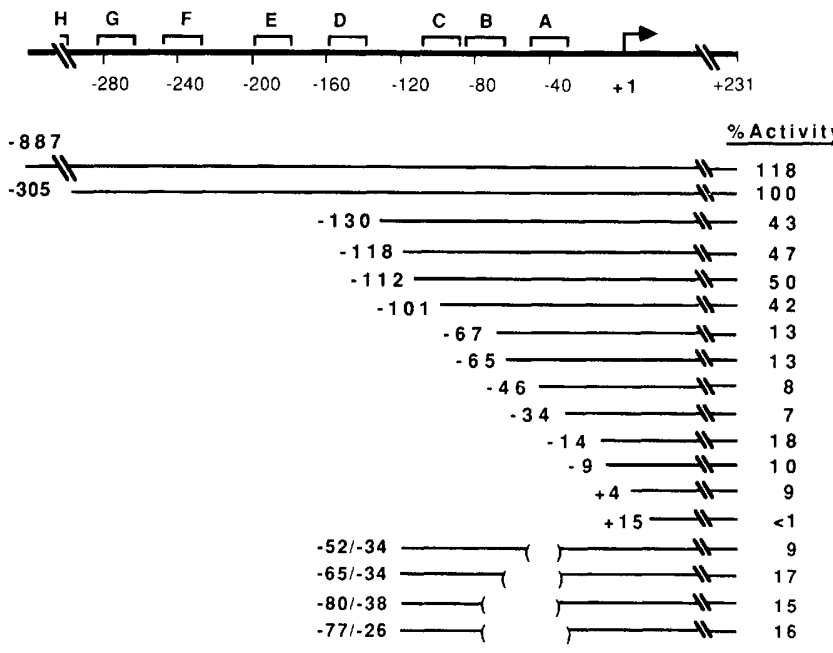

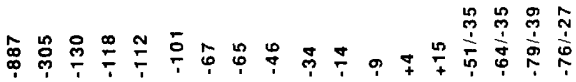

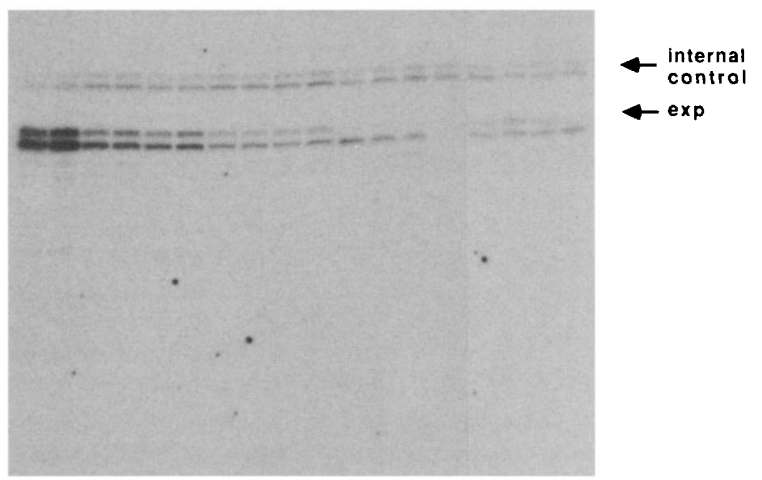

B
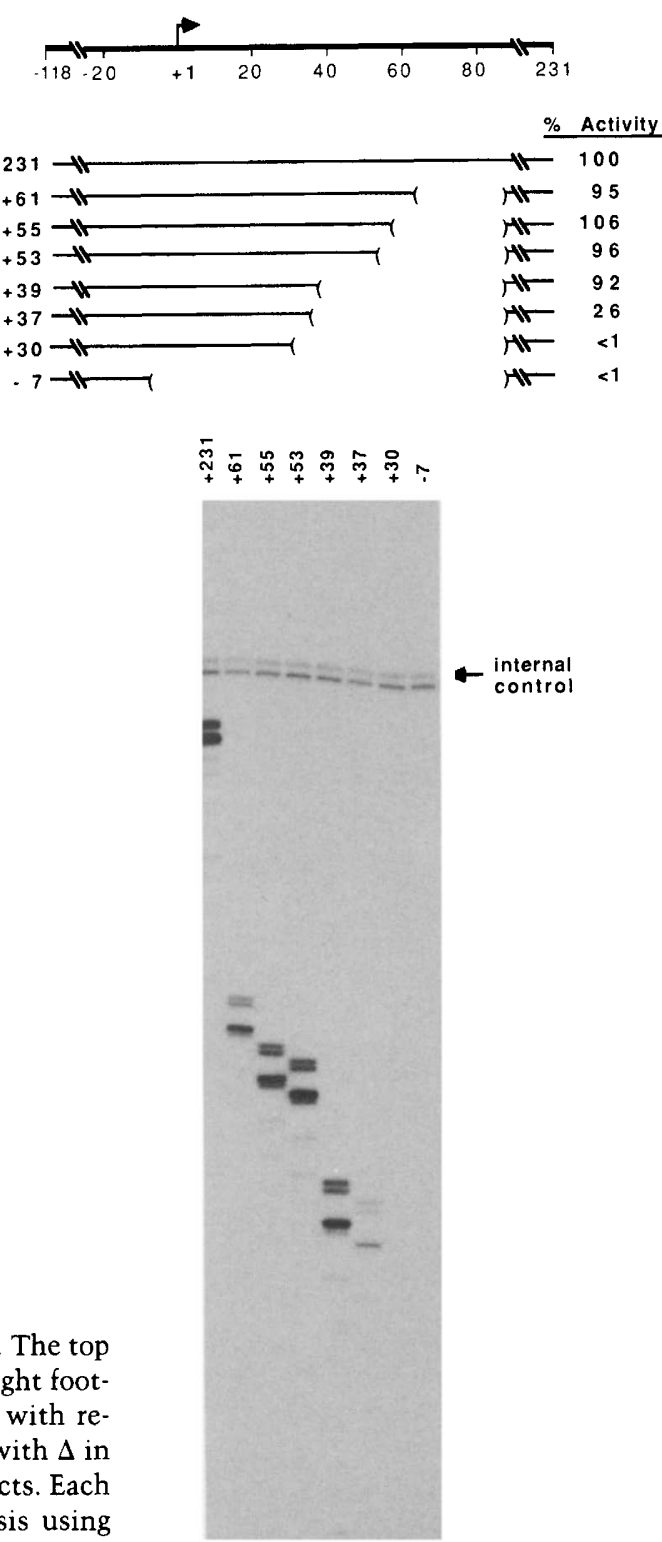

Figure 6. Transcription of promoter deletion mutants. (A) Upstream deletions. The top line represents engrailed genomic DNA to which the first initiation site and eight footprinted regions have been mapped. The mutant templates have been labeled with respect to the upstream end points of the retained upstream sequence (prefixed with $\Delta$ in the text). The lines represent engrailed genomic DNA left intact in the constructs. Each template was assayed for transcriptional activity by primer extension analysis using primer 2. Each transcription reaction contained $8 \mu \mathrm{g} / \mathrm{ml}$ mutant template, $2 \mu \mathrm{g} / \mathrm{ml}$ internal control template, and $2.4 \mu \mathrm{g} / \mathrm{ml}$ crude extract. $(B)$ Downstream deletions. Templates are labeled as described in the text. Reaction conditions were as in $A$.

metric values were compared to that of template $\Delta-305$, which was arbitrarily assigned a value of $100 \%$ (Fig. 6A).

A direct correlation between promoter length and template efficiency was observed: As the length of upstream sequence decreased, transcriptional activity decreased in discrete steps. Activity decreased twofold with template $\Delta-130$, decreased little further with templates $\Delta-118, \Delta-112$, and $\Delta-101$, and decreased an additional threefold with template $\Delta-67$. These quantitative changes correlate with the presence of protected regions $B$ and $C$ between positions -67 and -105 , and regions $D$ through $G$ between positions -138 and -283 . No change in the relative yield from the four start sites was observed. These results suggest that the sequence- specific DNA-binding activities specific for the engrailed promoter play a major role in the efficiency of the initiation reaction.

A similar conclusion was suggested by the behavior of mutant templates with a internal deletion. These deletion mutants lack between 16 and 49 bp within the region bounded by positions -80 and -26 , and are designated by the borders of their deletion end points. Templates $\Delta-80 /-38$, and $\Delta-77 /-26$ remove sequences that include both regions $A$ and $B$; their transcription was reduced by approximately $85 \%$. Templates $\Delta-51 /-35$ and $\Delta-65 /-34$ remove only sequences within and/or around region $\mathrm{A}_{\text {; }}$ their activities were reduced by $83-91 \%$. The fact that deletion of region A alone affects transcription as extensively as deletion of 
region $\mathrm{A}$ and $\mathrm{B}$ argues either that spacing of region $\mathrm{A}$ relative to the initiation sites affects template efficiency or that this most proximal binding site plays a special role in this promoter. However, these results are still consistent with the hypothesis that the sequence-specific DNA-binding activities detected in this region are intimately involved with engrailed transcription.

All templates that retained 14 or fewer residues upstream of position +1 supported initiation only from sites +5 and +6 . The inability of the $\Delta-14$ template or the $\Delta-77 /-26$ internal deletion mutant to utilize initiation sites +1 and +2 suggests that engrailed DNA sequences between position -14 and -34 (the most proximal residue of DNA-binding region $\mathrm{A}$ ) are used by the transcription apparatus in scanning the promoter sequence for the normal initiation sites. Interestingly, transcription was detectable from template $\Delta+4$, even though all upstream sequences, including initiation sites +1 and +2 , are deleted, and only a single base pair upstream of initiation site +5 is retained. The capacity of templates lacking all of the upstream promoter sequences to support transcription, albeit at a low level, implies that sequences within the transcribed region are recognized by the transcriptional machinery that initiates RNA synthesis.

\section{A region within the engrailed transcription unit is essential for transcription in vitro}

To determine if sequences within the nontranslated leader of the engrailed transcription unit are involved in the initiation reaction, templates were constructed that deleted downstream sequences. These leader sequence deletion mutants had varying amounts of DNA deleted between positions -7 and +127 , but all retained in common sequences upstream from -7 and downstream from +127 (Fig. 6B; designation of mutants is by their deletion endpoint closest to residue +11 . Transcriptional activity of these DNAs was measured using a primer extension assay in the presence of the control insertion template and the crude extract. Since these deletion mutants remove sequences from within the transcription unit, the lengths of the transcripts and of the primer extension products were correspondingly shortened. Removal of sequences between +39 and +124 did not affect initiation quantitatively or qualitatively. In contrast, the transcription efficiency of the $\Delta+37$ DNA (which lacks sequences between +37 and +124 ) was lowered at all four sites by approximately $75 \%$. The $\Delta+30$ mutant was essentially inactive. We conclude that there is a region within the first 38 residues downstream of site +1 that is essential for transcription.

\section{Region C competitor DNA specifically blocks high level transcription of the engrailed promoter}

To further evaluate the role of the DNA-binding proteins in promoting transcription, the activities of templates $\Delta-118$ and $\Delta-34$ were determined in the presence of region $\mathrm{C}$ oligonucleotide at concentrations pre- viously shown (Fig. 5A) to suppress protection from DNase I digestion in regions $\mathrm{A}$ through $\mathrm{F}$ and region $\mathrm{H}$. In these experiments, the Adh proximal promoter served as the control template since this promoter does not contain the GAGAG (or CTCTC) pentamer. Again, template efficiencies were determined from densitometric scans of the autoradiograms (Fig. 7). Transcription of template $\Delta-118$, which contains regions $\mathrm{A}, \mathrm{B}$, and $\mathrm{C}$, decreased to $22 \%$ of its maximal level as the ratio of competitor DNA to template was increased. In contrast, the competitor had no appreciable effect on transcription of template $\Delta-34$. This template has all upstream binding sites deleted; its activity in the absence of competitor is comparable to template $\Delta-118$ in the presence of competitor. These results confirm the notion that the proteins that bind to the GAGAG (or CTCTC) pentamer sites play a major role in modulating this gene's transcription.

Similar experiments were carried out using the 60-bp AvaI/DdeI DNA fragment containing region $\mathrm{G}$ as the competitor (data not shown). No decrease in transcription was detected with templates containing region G. Thus, it is possible that the DNA-binding activity that recognizes region $G$ plays no role in engrailed transcription per se. However, given the sizable distance (263 bp) of region $G$ from the initiation sites, the failure to detect an effect on transcription is more likely due to the insensitivity of in vitro transcription assays to far upstream sequences. Efforts to address this question by moving the region $\mathrm{G}$ sequence closer to the initiation sites are currently under way.

\section{In vivo transcription has similar upstream and downstream sequence requirements}

To evaluate the importance of the sequences implicated by in vitro initiation assays, transcription was also quantitated in Drosophila tissue culture cells. Various lengths of upstream and downstream promoter sequences were fused with sequences encoding the enzyme chloramphenicol acetyl transferase (CAT), and plasmids with these fusion gene constructs were transfected into Drosophila Schneider 2 cells. To control for transfection efficiency, a plasmid containing a fusion of approximately $3.5 \mathrm{~kb}$ of the upstream engrailed promoter with the coding sequences of $E$. coli lac $Z$ was transfected simultaneously. Forty-eight hours after transfection, extracts from the transfected cells were prepared, and CAT and $\beta$-galactosidase activities were measured.

CAT fusion genes with various lengths of upstream promoter sequences retained the first 127 bp downstream from the first initiation site. As with the in vitro primer extension experiments, template $\Delta-305 \mathrm{DM} 26$ was arbitrarily assigned a transcriptional value of $100 \%$ (Fig. 8A). CAT activity decreased 3 -fold with template $\Delta-118 \mathrm{DM} 26$, and 11 -fold with template $\Delta-38 \mathrm{DM} 26$. Template $\Delta+2$ DM26 reproducibly retained only $3 \%$ of the maximal transcription activity.

Four CAT fusion genes with various lengths of the 
Figure 7. Transcription of engrailed templates in the presence of competitor DNA. The autoradiogram displays the primer extension products of templates $\Delta-118$ and $\Delta-34$ in the absence $\{0 \mid$ or presence $(40,200)$ of increasing concentrations of double-stranded region $\mathrm{C}$ oligonucleotide. Reaction conditions were identical to those described in the legend to Fig. 6 except that the Adh proximal promoter was used as the internal control.
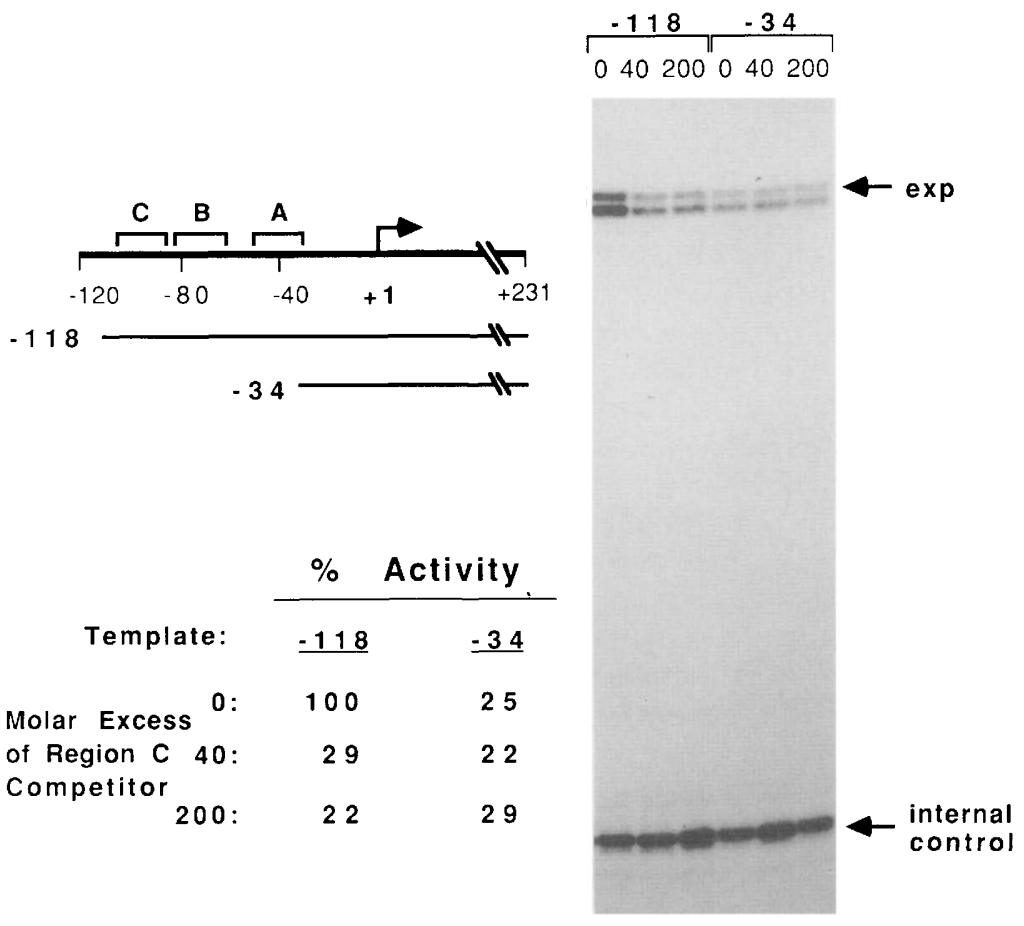

nontranslated leader were examined. These templates retained $118 \mathrm{bp}$ of upstream sequence, and either 127 , 39,37 , or $30 \mathrm{bp}$ of downstream sequence. Template $\Delta+127 \mathrm{DM} 26$ was assigned a transcriptional value of $100 \%$ (Fig. 8B). CAT activity in extracts of cells transfected with template $\Delta+39$ DM 26 was reduced by $54 \%$ (Compared to a $10 \%$ decrease that was observed in vitro, see Fig. 6B). The relative activity of template $\Delta+37 \mathrm{DM} 26(23 \%)$, was virtually identical to the in vitro efficiency. Template $\Delta+30 \mathrm{DM} 26$ had only $3 \%$ activity relative to template $\Delta+127 \mathrm{DM} 26$, thus confirming that sequences within the transcribed region of the engrailed gene are important for transcription. We conclude that both in vivo transcription activity and in vitro initiation efficiency depend on the same upstream and downstream sequences, and that the in vitro assays portray the initiation reaction faithfully.

\section{Discussion}

In this first investigation into the molecular mechanisms that directly regulate expression of the engrailed gene, we found that the engrailed promoter is unusual in several respects. It has neither a TATA box nor a CAAT element, sequences found in many eukaryotic promoters and thought to be important for RNA polymerase II recognition (Shenk 1981). Perhaps the absence of these sequences accounts for the multiple sites of initiation we observed for the engrailed gene in vitro and in vivo, and for the relatively low activity of the engrailed promoter in the in vitro transcription reaction (Fig. 1). The other promoters assayed in the in vitro system (Adh, Actin 5C, and fushi tarazu) have TATA homologies and are all approximately an order of magnitude more efficient. This suggests that some sequence and protein components that confer specificity to RNA polymerase are different for the engrailed gene than for these other genes.

Features of the engrailed promoter that were unexpected in view of the extraordinary size of the engrailed regulatory region were the high density of functional sequence elements within the first $400 \mathrm{bp}$ upstream of the sites of initiation, and the presence of a critical downstream sequence element. Eight distinct regions in this upstream region were recognized by sequence-specific DNA-binding activities. Interestingly, competition DNA-binding studies suggested that seven of the eight binding sites are recognized by the same protein, implying that several copies of this protein are involved in initiating engrailed transcription. Since binding was observed in the absence of RNA polymerase II, the function of the DNA binding is likely to be in the early steps of the initiation process (Hawley and Roeder 1985).

The identified downstream sequence is necessary and, for two of the four sites of initiation, sufficient for at least low levels of transcription. Deletion mutants that lack all of the upstream sequences and retain only the residues four nucleotides downstream from the first initiation site are nevertheless active for the two remaining sites of initiation. The overall template efficiency of such mutants was reduced 10 -fold relative to templates with 300 upstream residues. The nature of the role of downstream sequences is unclear, although the close proximity of the essential region to the initiation sites suggests that the RNA polymerase or proteins with which it is directly associated interact with the sequence. A similar requirement for downstream sequences has been observed previously for the Drosophila 
Ultrabithorax (M. Biggin, pers. comm.) and 74E ecdysone-responsive (C. Thummel, pers. comm.) genes.

Although we have not yet identified the proteins that bind to sequences within $350 \mathrm{bp}$ upstream of the sites of initiation, it is unlikely that they are previously isolated transcription factors. For example, no detectable homology was found between these regions of the engrailed promoter and the sequences recognized by either HSTF, a heat shock factor (Parker and Topol 1984b), or Adfl, an Adh gene binding protein (Heberlein et al. 1985). Several aspects of the binding sequences within the engrailed promoter are, however, noteworthy.

Six of the eight upstream regions (regions A, B, C, E, F, and $\mathrm{H}$ ) have in common the sequence GAGAG in the middle of each site, but little additional homology. Region D contains the related sequence GAGTG. Given that competition studies suggested that these sites are recognized by the same binding activity, the pentamer may form a core recognition sequence for the same DNA-binding protein. The importance of region $\mathrm{A}$ is also suggested by the existence of a homologous se- quence in another Drosophila gene. Eleven of thirteen residues $(-39$ to -52$)$ in region $A$ are homologous with a sequence in the invected gene $(\mathrm{K}$. Coleman and $\mathrm{T}$. Kornberg, unpubl.). The region of homology in the invected sequence is in a similar location relative to the site of transcription initiation (from positions -23 to $-37)$. The invected sequence is also protected from DNase I cleavage by DNA-binding activities in the H.4 and D.1 fractions (W. Soeller, K. Coleman, and T. Kornberg, unpubl.|, as is region A of engrailed. Since the invected gene is closely related to the engrailed gene in sequence and pattern of expression [it has a homeobox that is virtually identical to that of engrailed (Poole et al. 1985 ) and it is also expressed exclusively in posterior compartment cells (Coleman et al. 1987)], we speculate that homologous sequences in the promoter regions of these genes help to orchestrate their coordinate regulation.

We have noted other homologies in the regions protected from DNase I digestion. Region B contains 9 of 13 base pairs identical to an upstream region of the Ultra-

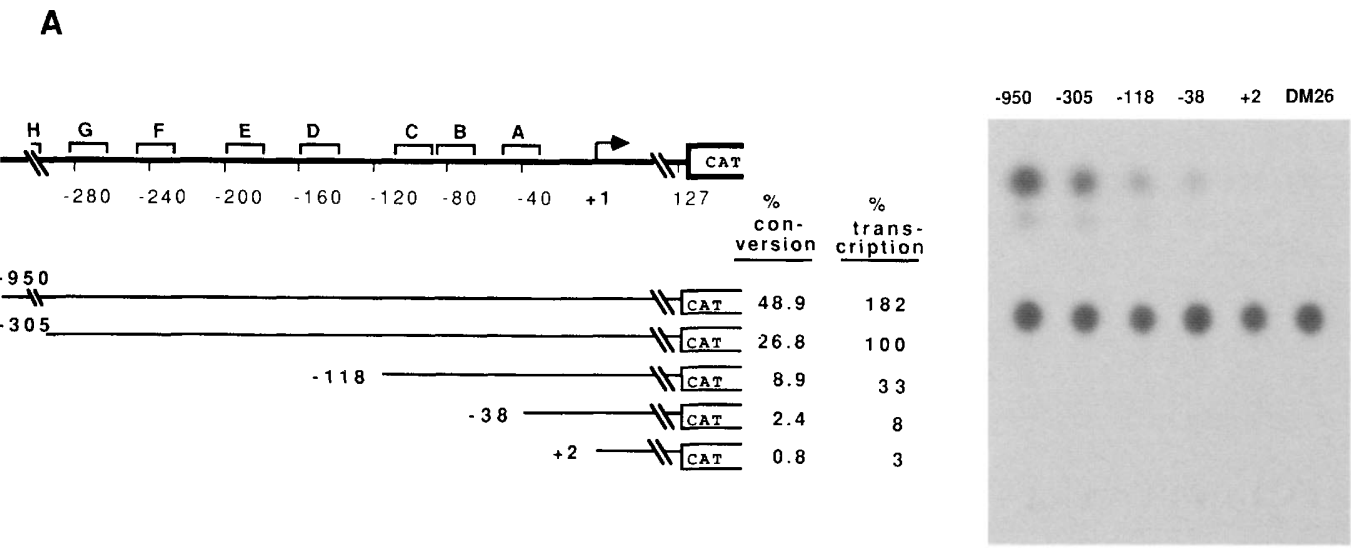

B
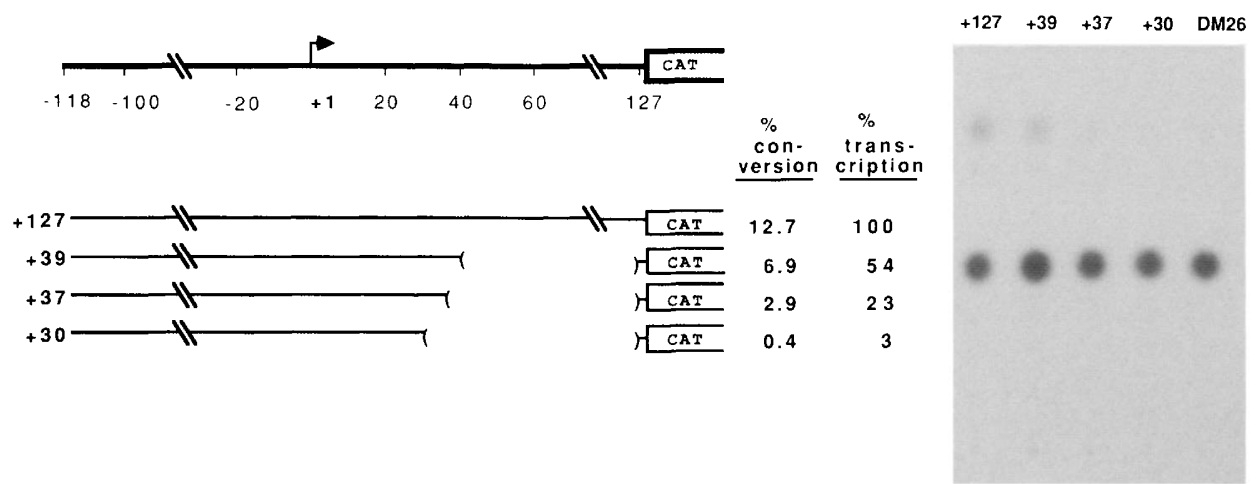

Figure 8. Transient expression assays of upstream and downstream deletion mutant templates. $(A)$ engrailed templates labeled $\Delta$-DM26 and containing various lengths of upstream sequence were fused to a reporter gene coding for CAT as described in Experimental procedures and were transfected with a $\beta$-galactosidase control template into Schneider 2 cells. (\% conversion) The fraction of chloramphenicol substrate converted to acetylated forms. DM26 is the CAT plasmid vector with no inserted promoter present. Results reflect values obtained after normalizing $\beta$-galactosidase activity measured in each sample and subtracting background levels determined by transfection with pDM26 alone. CAT assays were carried out as described by Gorman et al. (1982) at $37^{\circ} \mathrm{C}$ for 5 min using $50 \mu \mathrm{g}$ protein extract per assay. (B) Corresponding engrailed templates with downstream deletions fused to the CAT reporter gene. 
bithorax promoter that can be protected from DNase I digestion (M. Biggin, pers. comm.). Likewise, region C has a significant degree of identity with an additional upstream protected region of the Ultrabithorax gene ( $M$. Biggin, pers. comm.), and an upstream region of the fushi tarazu gene $(-102$ to -114 relative to the start site reported by Laughon and Scott 1984). Region G shares no obvious homology with the other six engrailed upstream sites. However, it does possess a significant degree of dyad symmetry. Such symmetry in a DNA-binding site is characteristic of DNA sequences bound by certain transcription factors (Topol et al. 1985; Ptashne 1986). In addition, this region shares a high degree of sequence similarity with an element discovered in the dopa decarboxylase (Ddc) promoter of Drosophila melanogaster and $D$. virilis. This element, situated between positions -56 and -73 in the D. melanogaster promoter, is identical to engrailed region $G$ at 10 of 13 nucleotide residues (overlapping but not entirely coincident with the stretch of dyad symmetry|. It has been shown to be essential for expression of Ddc in both the larval and adult nervous system (Scholnick et al. 1986). Since engrailed function is required in the adult nervous system (Lawrence and Johnston 1984) and since engrailed is expressed in the embryonic nervous system (DiNardo et al. 1985; C. Hama and T. Kornberg, in prep.|, one may speculate that region $\mathrm{G}$ and its binding protein are involved in central nervous system-specific expression. This notion is consistent with our preliminary results that indicate the region $\mathrm{G}$ binding activity to be present in embryo but not tissue culture extracts (data not shown.)

We have demonstrated that the activity responsible for protection of the GAGAG sites from DNase digestion also modulates maximal engrailed transcription in vitro. Whether this activity or the GAGAG sites are involved in conferring spatial or stage specificity on engrailed expression is not known. However, results of Pelement-mediated transformation experiments utilizing engrailed promoter- $\beta$-galactosidase DNA fusion constructions argue that these sites are not sufficient for tissue or stage specificity. Transformants containing constructs with only $1 \mathrm{~kb}$ of upstream sequence do not display a clear striping pattern. For a wild-type engrailed expression pattern to develop in the epidermis and central nervous system of the embryo, at least $7.5 \mathrm{~kb}$ of upstream sequence are required (C. Hama and T. Kornberg, in prep.). Dissection and mapping of cis-acting elements within this $7.5-\mathrm{kb}$ region by such transformation experiments will allow us to test promising candidates for their effect on engrailed transcription in vitro. Such an approach should allow us to identify, purify, and characterize trans-acting activities responsible for the normal tissue-specific gene regulation.

It will be interesting to determine whether some of the activities responsible for protecting the engrailed promoter from DNase I digestion are also responsible for modulating transcription of the Ultrabithorax, fushi tarazu, even-skipped, hairy, or any other of the array of genes responsible for segmentation and body pattern in Drosophila. As noted in the introductory section, studies of various mutant embryos suggest that genes such as fushi tarazu, even-skipped, and engrailed have cross-regulatory interactions. In vitro transcription reactions should help us understand the nature of these interactions.

\section{Experimental procedures}

\section{Preparation of the embryo extract}

Oregon $\mathrm{R}$ wild-type flies were grown under standard conditions at $25^{\circ} \mathrm{C}$ in population cages (Kriegstein and Hogness 1974). Embryos of various ages, usually $2-12 \mathrm{hr}$ after egg laying, were collected on corn meal-agar trays, harvested with a solution of $0.7 \% \mathrm{NaCl}, 0.04 \%$ Triton X-100 (Sigma), and dechorionated by immersion in $2.25 \%$ sodium hypochlorite $(1 / 2$ dilution of commercial bleach) for $90 \mathrm{sec}$. After extensive rinsing with sodium chloride/Triton solution and a final rinse with $\mathrm{H}_{2} \mathrm{O}$, the embryos were quickly blotted dry and weighed. All subsequent steps were carried out at $4^{\circ} \mathrm{C}$.

The initial steps for isolation of nuclei closely follows the procedure described in Kuo et al. 1982. The embryos were suspended in $4 \mathrm{ml} / \mathrm{gram}$ of embryos in buffer A $[0.35 \mathrm{M}$ sucrose, 15 mM HEPES (pH 7.6), $10 \mathrm{~mm} \mathrm{KCl}, 5 \mathrm{~mm} \mathrm{MgCl} 2,0.1 \mathrm{~mm}$ EDTA, $0.5 \mathrm{~mm}$ EGTA, $1 \mathrm{~mm}$ DTT, $1 \mathrm{~mm}$ PMSF, $1 \mu \mathrm{g} / \mathrm{ml}$ leupeptin (Boehringer-Mannheim)], and were homogenized by six strokes with a motorized Teflon pestle (G.K. Heller, Floral Park, New York| followed by six strokes with a glass-glass dounce homogenizer (type B pestle). The milky-white homogenate was passed through three layers of pre-wetted Miracloth (Calbiochem) and centrifuged at $4000 \mathrm{rpm}$ in a Beckmann JA20 rotor for $10 \mathrm{~min}$. Pellets were resuspended gently in buffer A $(2 \mathrm{ml} / \mathrm{g}$ embryos $)$, and the nuclei in $6-\mathrm{ml}$ aliquots were layered over an equal volume of buffer $\mathrm{B}[\mathrm{O} .8 \mathrm{~mm}$ sucrose, $15 \mathrm{mM}$ HEPES (ph 7.6), 10 $\mathrm{mM} \mathrm{KCl}, 5 \mathrm{~mm} \mathrm{MgCl}, 0.1 \mathrm{~mm}$ EDTA, $0.5 \mathrm{~mm}$ EGTA, $1 \mathrm{~mm}$ DTT, $1 \mathrm{mM}$ PMSF, $10 \mu \mathrm{g} / \mathrm{ml}$ leupeptin ] in $12-\mathrm{ml}$ graduated polycarbonate tubes. Nuclei were pelleted by centrifugation in a Beckman JS-14 rotor at $5000 \mathrm{rpm}$ for $10 \mathrm{~min}$.

Subsequent steps closely followed the procedure for preparation of $K_{c}$ nuclear extracts (Parker and Topol 1984a; Heberlein et al. 1985). After noting the volume of the nuclear pellet and removing the supernatant by aspiration, nuclei were resuspended in 4 volumes of buffer $\mathrm{C}$ ( 15 mM HEPES ( $\mathrm{pH} 7.6), 110$ mM KCl, 3 mM MgCl, $0.1 \mathrm{~mm}$ EDTA, I mM DTT, 1 mM PMSF, and $10 \mu \mathrm{g} / \mathrm{ml}$ leupeptin ] and transferred to Beckmann 60Ti polycarbonate tubes. Ammonium sulfate $4.0 \mathrm{M},(\mathrm{pH} 7.6)$ was added stepwise to a final concentration of $0.36 \mathrm{~mm}$, and lysis of the nuclei was accomplished by gentle mixing on a nutator (Clay Adams) for $30 \mathrm{~min}$. The extract was clarified by centrifugation at 35,000 rpm for $1 \mathrm{hr}$ in a Beckman 60Ti rotor. Material floating on the supernatant surface was removed by aspiration. The supernatant was collected by decantation and the active protein fraction was precipitated by the stepwise addition of 0.3 grams of solid ammonium sulfate per milliliter of supernatant. After stirring for $15 \mathrm{~min}$, the precipitate was collected by centrifugation at $15,000 \mathrm{rpm}$ for $15 \mathrm{~min}$ in a JA20 rotor. The pellet was gently resuspended with a glass rod in a volume of buffer HEMG | $25 \mathrm{mM}$ HEPES (pH 7.6), $40 \mathrm{~mm} \mathrm{KCl}, 12.5 \mathrm{~mm} \mathrm{MgCl}_{2}$, $0.1 \mathrm{~mm}$ EDTA, I mM DTT, $1 \mathrm{~mm}$ PMSF, $10 \mu \mathrm{g} / \mathrm{ml}$ leupeptin, $10 \%$ glycerol (see Heberlein et al. 1985) lequal to one-third the volume of the nuclear pellet. The resulting suspension was clarified by centrifugation $(10,000 \mathrm{rpm} / \mathrm{JA} 20$ rotor/10 min) and dialyzed against buffer HEMG until the conductivity was equivalent to a reading obtained with HEMG, $0.12 \mathrm{M} \mathrm{KCl}$ (approximately $3 \mathrm{hr}$. Precipitates were removed by centrifugation 
(10,000 $\mathrm{rpm} / \mathrm{JA} 20$ rotor/10 $\mathrm{min})$ and the clarified nuclear extract was either frozen in small aliquots and stored at $-80^{\circ} \mathrm{C}$ or loaded directly onto a heparin-Sepharose column. The protein concentrations of the extracts varied from 20 to $30 \mathrm{mg} / \mathrm{ml}$ as determined by the method of Bradford (Bradford 1976).

\section{Fractionation of the embryo nuclear extract}

Nuclear extract was applied to a heparin-Sepharose CL-6B column (Pharmacia, $1.3 \mathrm{ml}$ extract $/ \mathrm{ml}$ bed volume), equilibrated with HEMG, $0.1 \mathrm{M} \mathrm{KCl}$ and washed with 3 column volumes of the same buffer. Protein was eluted with 2 column volumes of $\mathrm{HEMG}, 0.4 \mathrm{M} \mathrm{KCl}$, and the pooled fractions were dialyzed against $\mathrm{HEMG}, 40 \mathrm{mM} \mathrm{KCl}$ to a conductivity equivalent to that obtained with HEMG, $0.12 \mathrm{M} \mathrm{KCl}$. The dialyzed protein fraction (H.4, $8 \mathrm{mg} / \mathrm{ml}$ protein) was applied to a column

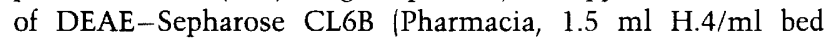
volume), and the column was washed with 3 volumes of HEMG, $0.1 \mathrm{M} \mathrm{KCl}$, and eluted with 2 volumes of HEMG, $0.25 \mathrm{M}$ $\mathrm{KCl}$. Proteins flowing through the DEAE-Sepharose (D.1) or eluted with $0.25 \mathrm{M} \mathrm{KCl}$ (D.25) were pooled, aliquoted, frozen in liquid nitrogen, and stored at $-80^{\circ} \mathrm{C}$.

\section{In vitro transcription}

Run-off assays were performed essentially as described in Parker and Topol (1984a). In a final volume of $25 \mu \mathrm{l}, 25 \mathrm{~mm}$ HEPES (pH 7.6), $6 \mathrm{mM} \mathrm{MgCl}_{2}, 50 \mathrm{~mm} \mathrm{KCl}, 1 \mathrm{~mm} \mathrm{DTT}, 0.05 \mathrm{~mm}$ EDTA, $3 \%$ glycerol, $500 \mu \mathrm{mm}$ each of ATP, CTP, and UTP, 50 $\mu \mathrm{M}$ GTP, $6 \mu \mathrm{Ci}$ of $410 \mathrm{Ci} / \mathrm{mole}$ [32PGTP] (Amersham), 4-20 $\mu \mathrm{g} / \mathrm{ml}$ of linearized DNA template, and $40-160 \mu \mathrm{g}$ crude nuclear extract were incubated for $30 \mathrm{~min}$ at $25^{\circ} \mathrm{C}$. Reactions were stopped by addition of $4 \mu \mathrm{l}$ of a stop mix consisting of 200 $\mu \mathrm{g} / \mathrm{ml}$ yeast RNA and $40 \mathrm{~mm}$ EDTA. The volume was increased to $100 \mu$ l with $10 \mathrm{~mm}$ HEPES $(\mathrm{pH} 7.6), 1 \mathrm{~mm}$ EDTA, and unincorporated [32PGTP] was removed by spin dialysis through a 1-ml G-50 column (Maniatis et al. 1982). Samples were extracted twice with phenol/chloroform and were precipitated with ethanol. Precipitated RNA product was loaded on a $1.4 \%$ formaldehyde-agarose (HGT; FMC) gel and electrophoresed for $3 \mathrm{hr}$ at $6 \mathrm{~V} / \mathrm{cm}$. The gel was dried onto DE81 paper (Whatman), and the bands were visualized by exposure overnight to Kodak XAR film at $-80^{\circ} \mathrm{C}$ with a Dupont Cronex screen.

Primer extension assays consisted of two steps. The first was identical to the run-off assay except that no labeled nucleoside triphosphate was present and the templates were not linearized with restriction endonucleases. In the second step, the unlabeled RNA product was resuspended in $3 \mu \mathrm{H} \mathrm{H}_{2} \mathrm{O}$ to which was added $2 \mu \mathrm{l}$ of an end-labeled, synthetic 20-nucleotide-long primer at a concentration of $0.5 \mu \mathrm{M}$ and a sp. act. of $3 \times 10^{6}$ $\mathrm{cpm} / \mathrm{pmole}$ primer. Two engrailed specific primers were used: primer 1 hybridized to the RNA from positions +58 to +39 , inclusive; primer 2 hybridized from positions +167 to +148 . Adh proximal promoter activity was monitored with a 27 -base oligonucleotide specific for this gene (gift of V. Heberlein). The primer was hybridized to the RNA by incubation at $75^{\circ} \mathrm{C}$ for 2 min, at $55^{\circ} \mathrm{C}$ for $20 \mathrm{~min}$, and at $25^{\circ} \mathrm{C}$ for $10 \mathrm{~min}$. The hybridized primers were elongated with murine reverse transcriptase 1200 units, BRL) in the presence of $50 \mathrm{~mm}$ Tris- $\mathrm{HCl}$ (pH 7.9), $50 \mathrm{~mm}$ $\mathrm{KCl}, 10 \mathrm{~mm} \mathrm{MgCl} 2,500 \mu \mathrm{mm}$ each of dTTP, dATP, dGTP, and dCTP, $100 \mu \mathrm{g} / \mathrm{ml}$ actinomycin D, and 20 units of RNAs in (Promega) in a total volume of $10 \mu \mathrm{l}$. The reactions were incubated for $1 \mathrm{hr}$ at $37^{\circ} \mathrm{C}$ followed by the addition of an equal volume of loading dye mix (bromophenol blue and xylene cyanol in $90 \%$ formamide). Aliquots were loaded onto $6 \%$ acrylamide (20:1 acrylamide/bisacrylamide)/7 $\mathrm{M}$ urea sequencing gels $(60 \mathrm{~cm} \times 20 \mathrm{~cm} \times 0.4 \mathrm{~mm})$ and run at $30 \mathrm{~W}$ for $2 \mathrm{hr}$ before drying and exposure to film.

\section{DNase I protection assays}

Footprint reactions were performed in a volume of $20 \mu 1$, containing $25 \mathrm{mM}$ HEPES (pH 7.6), $50 \mathrm{mM} \mathrm{KCl}, 6 \mathrm{mM} \mathrm{MgCl}_{2}, 0.1$ mM EDTA, 10-20 ng of end-labeled DNA fragment, and up to $10 \mu \mathrm{l}$ of the various protein fractions. Reactions were assembled on ice in the absence of the DNA probe and allowed to equilibrate for $10 \mathrm{~min}$. DNA probe was added and the reactions were incubated on ice for an additional $15 \mathrm{~min}$. The reactions were then placed at room temperature, diluted twofold with a solution of $10 \mathrm{mM} \mathrm{CaCl}_{2}$ and $20 \mathrm{mM} \mathrm{MgCl}_{2}$ and digested with an appropriate amount of DNase I (DPRF, Worthington; 1.6 to $20 \mathrm{ng}$ / for $1 \mathrm{~min}$. The reaction was stopped with $100 \mu \mathrm{l}$ stop $\mathrm{mix}$ $(0.1 \%$ SDS, $200 \mu \mathrm{g} / \mathrm{ml}$ RNA carrier, $20 \mathrm{~mm}$ EDTA, $0.2 \mathrm{M} \mathrm{KCl})$. Reaction products were extracted with phenol/chloroform, precipitated with ethanol, and electrophoresed on $6 \%$ or $10 \%$ acrylamide $(20: 1$ acrylamide/bisacrylamide $) / 7 \mathrm{M}$ urea sequencing gels.

\section{Cloned segments of Drosophila DNA used for in vitro transcription}

DNA fragments used as templates for in vitro transcription included: a plasmid containing the Drosophila actin 5C gene in an $8.7-\mathrm{kb}$ EcoRI-SalI segment of the plasmid pDmA2 (Fyrberg et al. 1980); the distal and proximal promoters for alcohol dehydrogenase (Adh) in a $4.7-\mathrm{kb}$ EcoRI fragment from plasmid pl3E-3 cloned into pUCl3 (Heberlein et al. 1985); and the promoter for fushi tarazu in a $3.5-\mathrm{kb}$ HindIII fragment.

Templates for transcription of the engrailed gene were derived from plasmid p6:4.7, a 4.7-kb EcoRI fragment of $\lambda$ phage E7 (Kuner et al. 1985). The template $\Delta-887$ is a PvuII-PstI fragment (extending from -887 to +231 ) of the $4.7-\mathrm{kb}$ EcoRI fragment cloned into pEMBL 18. Upstream deletion templates $\Delta-130$ and $\Delta-118$ were generated by the $\mathrm{DNase} \mathrm{I} / \mathrm{MnCl}_{2}$ method (Hong 1982); they retain 130 and 118 bp, respectively, of upstream sequence and $231 \mathrm{bp}$ of the engrailed transcribed region. The remaining upstream deletion mutants were derived from $\Delta-118$, which was linearized at the upstream end with HindIII, digested with exonuclease III and nuclease S1, treated with T4 DNA polymerase to fill in the ends, and recircularized with T4 DNA ligase (Henikoff 1984). With the exception of $\Delta+4$ and $\Delta+15$, each mutant retains various lengths of upstream regions and 231 bp of the downstream transcribed region. $\Delta+4$ and $\Delta+15$ retain no upstream sequences and only 228 and 216 bp of transcribed region, respectively.

For a control template, a 12-bp BamHI linker was inserted at a filled DdeI site (position +127 ) in $\Delta-118$. This control template, $\Delta-118 \mathrm{Bam}$, was also used to generate deletions from the downstream end. To introduce deletions, $\Delta-118 \mathrm{Bam}$ was linearized with BamHI, treated with exonuclease III and nuclease S1, and treated with T4 DNA polymerase to fill in the ends. These fragments were cleaved with Pst (at position +231 ) and ligated to a purified $B a m \mathrm{HI} / P_{\text {stI }}$ fragment (engrailed sequences +127 to +231 ) of $\Delta-118$ Bam, followed by end filling and recircularization. This scheme reintroduced the transcribed region from +127 to +231 , allowing use of primer 2 in the primer extension assays.

The internal deletion mutants $\Delta-52 /-34, \Delta-65 /-34$, $\Delta-80 /-38$, and $\Delta-77 /-26$ were derived from $\Delta-118$. This plasmid was linearized with $\mathrm{HpaI}$ at position -38 and was digested with exonuclease III and nuclease Sl prior to end filling and recircularization. This procedure resulted in the removal of between 16 and 49 bp within a region bounded by positions -80 and -26 .

To construct the engrailed-CAT fusion templates, various lengths of the engrailed promoter were joined to the polylinker 
directly upstream of the CAT coding sequences of plasmid pDM26 (Mismer and Rubin 1987) as follows: $\Delta-118 \mathrm{DM} 26$, with a $B a m H I$ fragment of $\Delta-118$ Bam containing 118 bp of upstream and $127 \mathrm{bp}$ of downstream engrailed sequences into the BamHI site; $\Delta-960 \mathrm{DM} 26$, with a ClaI/BamHI engrailed fragment $(-960$ to +127$)$ into Sall/BamHI-cut pDM26; $\Delta-305 \mathrm{DM} 26, \Delta-38 \mathrm{DM} 26$, and $\Delta+2 \mathrm{DM} 26$ from $\Delta-960 \mathrm{DM} 26$ after digestion with AvaI, HapI, and HincII nucleases, respectively. $\Delta-118 \mathrm{DM} 26$ derivatives with 39,37 , or 30 bp of downstream sequences were generated with $\mathrm{XbaI}-\mathrm{Bam} \mathrm{HI}$ fragments from deletion mutants $\Delta+39, \Delta+37$, and $\Delta+30$, respectively, and $\mathrm{XbaL} / \mathrm{BamHI}$-cut pDM26.

Transfections were carried out as described by DiNocera and Dawid (1983) using $10 \mu \mathrm{g}$ of template DNA and $1 \mu \mathrm{g}$ of the $\beta$-galactosidase control DNA per $60-\mathrm{mm}$ tissue culture plate. Cells were harvested after $48 \mathrm{hr}$ and assayed for CAT (Gorman et al. 1982) and $\beta$-galactosidase (Miller 1972) activity.

\section{Acknowledgments}

We thank G. Ennis, E. Fyrberg, M. Scott, and D. Mismer for providing BamHI linker, actin 5C, fushi tarazu, and pDM26 DNA, respectively; M. Biggin, U. Heberlein, E. Fodor, and R. Tjian for their help and advice; K. Coleman for sequence analysis of a number of the deletion derivatives; and the Weingart Foundation and National Institutes of Health for financial support.

\section{Reference}

Benyajati, C., N. Spoerel, H. Haymerle, and M. Ashburner. 1983. The messenger RNA for alcohol dehydrogenase in Drosophila melanogaster differs in its $5^{\prime}$ end in different development stages. Cell 33: 125-133.

Bradford, M.M. 1976. A rapid and sensitive methods for the quantitation of microgram quantities of protein utilizing the principle of protein-dye binding. Anal. Biochem. 72: 248254.

Coleman, K., S. Poole, M. Weir, W. Soeller, and T. Kornberg. 1987. The invected gene of Drosophila: Sequence analysis and expression studies reveal a close kinship with the engrailed gene. Genes Dev. 1: 19-28.

Coulter, D.E. and A.L. Greenleaf. 1982. Properties of mutationally altered RNA polymerase II of Drosophila. J. Biol. Chem. 257: 1945-1952.

Dignam, J.D., R.M. Lebovitz, and R.G. Roeder. 1983. Accurate transcription initiation by RNA polymerase II in a soluble extract from isolated mammalian nuclei. Nucleic Acids Res. 11: $1475-1489$.

DiNardo, S., M.M. Kuner, J. Theis, and P.H. O'Farrel. 1985. Development of embryonic pattern in D. melanogaster as revealed by accumulation of the nuclear engrailed protein. Cell 43: 59-69.

DiNocera, P.P. and I.B. Dawid. 1983. Transient expression of genes introduced in cultured cells of Drosophila. Proc. Natl. Acad. Sci. 80: 7095-7098.

Drees, B., Z. Ali, W.C. Soeller, K.G. Coleman, S.J. Poole, and T. Kornberg. 1987. The transcription unit of the Drosophila engrailed locus: An unusually small protein of a 70,000 base pair gene. EMBO I. 6: 2803-2809.

Dynan, W.S. and R. Tjian. 1983. Isolation of transcription factor that discriminate between different promoters recognized by RNA polymerase II. Cell 32: 669-680.

Fyrberg, E.A., K.L. Kindle, N. Davidson, and A. Sodja. 1980. The actin gene of Drosophila: A dispersed multigene family. Cell 19: 365-378.

Gorman, C.M., L.L. Moffat, and B.H. Howard. 1982. Recombi- nant genomes which express chloramphenicol acetyltransferase in mammalian cells. Mol. Cell. Biol. 2: 1044-1051.

Gorski, K., M. Carneiro, and U. Schibler. 1986. Tissue-specific in vitro transcription from the mouse albumin promoter. Cell 47: 767-776.

Harding, K., C. Rushlow, H. Doyle, T. Hoey, and M. Levine. 1986. Cross-regulatory interactions among pair-rule genes in Drosophila. Science 233: 953-959.

Hawley, D.K. and R.C. Roeder. 1985. Separation and partial characterization of 3 functional steps in transcription initiation by human RNA polymerase II. I. Biol. Chem. 260: 8163-8172.

Heberlein, U., B. Englund, and R. Tiian. 1985. Characterization of Drosophila transcription factors that activate the tandem promoters of the alcohol dehydrogenase gene. Cell 41: 965977.

Henikoff, S. 1984. Unidirectional digestion with exonuclease III creates targeted breakpoints for DNA sequences. Gene 28: $351-359$.

Hong, G. 1982. A systematic DNA sequencing strategy. J. Mol. Biol. 158: $539-549$.

Howard, K. and P. Ingham. 1986. Regulatory interactions between the segmentation genes fushi tarazu, hairy, and engrailed in the Drosophila blastoderm. Cell 44: 949-957.

Kim, W.-Y., and M.E. Dahmus. 1986. Immunochemical analysis of mammalian RNA polymerase II subspecies. I. Biol. Chem. 261: 14219-14225.

Kriegstein, H.J. and D.S. Hogness. 1974. Mechanism of DNA replication in Drosophila chromosomes: Structures of replication forks and evidence for bidirectionality. Proc. Natl. Acad. Sci. 71: 135-139.

Kuner, J.M., M. Nakanishi, Z. Ali, B. Drees, E. Gustavson, J. Theis, L. Kauver, T. Kornberg, and P.H. O'Farrell. 1985. Molecular cloning of engrailed: A gene involved in the development of pattern in Drosophila melanogaster. Cell 42: 309316.

Kuo, D.-H., H. Giloh, A. Blumenthal, and J.W. Sedat. 1982. A library of monoclonal antibodies to nuclear proteins from Drosophila melanogaster embryos. Exp. Cell Res. 142: 141154.

Laughon, A. and M.P. Scott. 1984. Sequence of a Drosophila segmentation gene: Protein structure homology with DNAbinding proteins. Nature 310: 25-31.

Lawrence, P. and P. Johnston. 1984. On the role of the engrailed gene in the internal organs of Drosophila. EMBO I. 3: 28392844.

Maniatis, T., E.F. Fritsch, and J. Sambrook. 1982. Molecular cloning: A laboratory manual. Cold Spring Harbor Laboratory, Cold Spring Harbor, New York.

Manley. J.L. 1983. Analysis of the expression of genes encoding animal mRNA by in vitro techniques. Prog. Nucleic Acid Res. Mol. Biol. 30: 195-244.

Miller, J. 1972. Experiments in molecular genetics. Cold Spring Harbor Laboratory, Cold Spring Habor, New York.

Mismer, D. and G.M. Rubin. 1987. Analysis of the promoter of the ninaE opsin gene in Drosophila melanogaster. Genetics 116: $565-578$.

Mizushima-Sugano, J. and R. Roeder. 1986. Cell-type-specific transcription of an immunoglobulin $\kappa$ light chain in vitro. Proc. Natl. Acad. Sci. 83: 8511-8151.

Parker, C.S. and J. Topol. 1984a. A Drosophila RNA polymerase II transcription factor contains a promoter region specific DNA binding activity. Cell 36: 357-369.

1984b. A Drosophila RNA polymerase II transcription factor binds to the regulatory site of an hsp 70 gene. Cell 37: $273-283$. 
Poole, S., L. Kauvar, B. Drees, and T. Kornberg. 1985. The engrailed locus of Drosophila: Structural analysis of an embryonic transcript. Cell 40: 37-43.

Ptashne, M. 1986. A genetic switch: Gene control and phaged. Blackwell Scientific Publications, Boston.

Scholnick, S., S. Bray, B. Morgan, C. McCormick, and J. Hirsh. 1986. CNS and hypoderm regulatory elements of the Drosophila melanogaster dopa decarboxylase gene. Science 234: 998-1002.

Shenk, T. 1981. Transcriptional control regions: Nucleotide sequence requirements for initiation by RNA polymerases II and III. Curr. Top. Microbiol. Immunol. 93: 25-46.

Topol, J., D. Ruden, and C.S. Parker. 1985. Sequence required for in vitro transcriptional activation of a Drosophila hsp 70 gene. Cell 4: 527-537.

Weir, M.P. and T. Kornberg. 1985. Pattern of engrailed and fushi tarazu transcripts reveal novel intermediate stages in Drosophila segmentation. Nature 318: 433-445. 


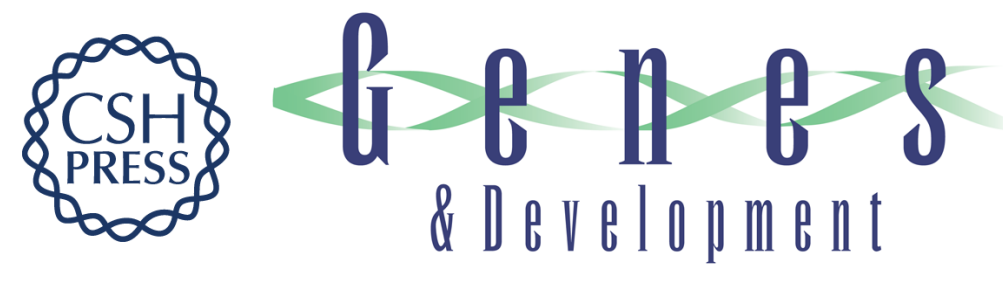

\section{In vitro transcription of the Drosophila engrailed gene.}

W C Soeller, S J Poole and T Kornberg

Genes Dev. 1988, 2:

Access the most recent version at doi:10.1101/gad.2.1.68

References This article cites 34 articles, 10 of which can be accessed free at: http://genesdev.cshlp.org/content/2/1/68.full.html\#ref-list-1

License

Email Alerting Receive free email alerts when new articles cite this article - sign up in the box at the top Service right corner of the article or click here.

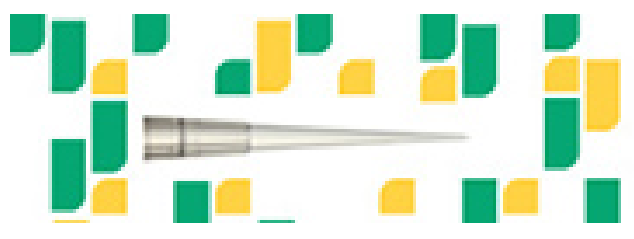

